\title{
Word wars and tobacco control: saying what needs saying that we don't yet know how to say, or saying it better
}

\author{
Ruth E Malone
}

\begin{abstract}
To help officially launch the Tobacco Control Blog, this month's Editorial has also been posted to the blog and is ready for your comments. The aim of this blog is to stimulate debate, generate ideas and explore new and, at times, controversial ideas. Increasing the opportunities for interaction between readers, authors, and editors is essential to ensuring that the journal remains on the leading edge in today's world of instant and constant digital communication. In keeping with this theme, editor Ruth Malone raises the issue of how important language is in defining and framing the tobacco pandemic and challenges readers to share their own creative ideas for "language weapons." To entice you to join the conversation and make a suggestion, the best idea will win a one-year online subscription to Tobacco Control.

The TC blog can be found here: http://blogs.bmj.com/tc/ We look forward to meeting you there. Tobacco Control Editorial Team
\end{abstract}

Some of the most impressive work in the global tobacco wars is never noticed within the battlefields of city councils, legislatures, regulatory agencies or courtrooms. Instead, it is carried out much more subtly, on the front lines of everyday word wars. Words not only represent and describe, they also reflect and constitute our very understanding of what the issues are: they 'make reality'. Smoking denormalisation and tobacco industry delegitimisation, so critical to 21 st century tobacco control efforts, did not just naturally extend from an earlier focus on telling individuals not to smoke and helping individuals quit one by one. Rather, a few thought leaders began to put into language fundamentally new ways of talking about tobacco as a societal problem. For example, the brilliant 'vector' analytic of LeGresley ${ }^{1}$ changed forever the way public health views the tobacco industry.

Contemporary philosopher Charles Taylor identified three important aspects of language ${ }^{2}$ : first, in language we formulate things, bringing to full awareness what we may have previously understood only implicitly. Taylor shows how, when we can't articulate something, we are also unable to decide how to focus on it, how

Correspondence to Professor Ruth E Malone, Department of Social and Behavioural Sciences, University of California, San Francisco, 3333 California St Suite 455, San Francisco, CA 94118, USA;

ruth.malone@ucsf.edu different aspects of it may be related, how it figures amidst other things. When we finally break through and find the words for it, this new language allows us to better understand its boundaries and grapple with it in new ways. Thus, when LeGresley and others pointed out in fresh language the parallels between tobacco companies and the mosquitoes that transmit malaria, they brought to the forefront of public attention the need to address the supply side of the tobacco disease epidemic.

Second, language puts things into a public space where we can share understandings-but beyond that, Taylor says, it actually creates that public space or shared vantage point. This is not merely a matter of communicating 'information'; it also creates an 'us'. Taylor gives an example of two people riding in a hot train car. One turns to the other and says, 'Whew, it's hot'. Each person already knows this; the language is not conveying anything new. What it is doing is putting into words their shared experience, and in so doing, creating a new shared space. The laughing recognition of a then-common experience that followed comedian George Carlin's quip that 'a smoking section in a restaurant is like a peeing section in a swimming pool' created a new space quickly shared by advocates in many places, who used it effectively to argue for $100 \%$ smokefree policies.

Finally, Taylor points out that language grounds our moral sense as human beings, enables us to draw distinctions about meaning based on understandings about what we value most. Language is 'constitutive': it shapes common understandings about our social relationships with one another, our practices, our aspirations and goals. Helping people understand that lung cancer was not always so common a disease, that we face an industrially produced epidemic, calls attention to the moral problem of corporations and individuals promoting and profiting from deadly products

In too many places even today, tobacco use is still taken for granted and if problematised at all, is understood primarily as an individual 'bad habit' rather than an ongoing failure by governments to provide adequate public health-based constraints on the disease-promoting practices of powerful corporate interests. ${ }^{3-5}$ This is why it is important for all of us to attend to how our language serves or undermines tobacco companies' preferred framing of 'smoking and health' issues, of cigarettes as a 'risky product' and of 'responsibility' as comprised primarily of providing 'information' in a decontextualised way. ${ }^{6}$

Instead, we should insist on talking about 'smoking and disease', 'deadly products' and corporate responsibility as acting in a way that is consistent with being fully accountable for the effects of the products one sells when they are used as intended. We should also discontinue discussion of 'giving up' smoking, a construction that makes becoming free of tobacco addiction a loss rather than a gain; we should stop calling our new pack labels 'graphic health warnings' and instead call them 'graphic disease warnings'. We also ought to stop calling tobacco addiction a 'habit', as though it were comparable to the habits of brushing one's teeth, eating cereal each morning for breakfast, or staying up late at night reading in bed.

As Chapman argues, 'epidemiologists' currency in debate is probabilistic data on risk, but this is not how communities define problems, nor why they can become outraged about low-risk issues, remain indifferent to some high-risk exposures or support some policy responses and not others." I Instead, new problems come to be defined through new definitions and arguments advanced by advocates using fresh language-or using old language in new ways. Tobacco Control's readers are always seeking innovation in how we talk about what we do and the tobacco industry is continually adapting itself to new circumstances, 
while reframing doing the same old thing as 'responsible'.

Do you have other ideas for new language weapons in the word wars? A free online one-year subscription to the journal awaits the best suggestion received. Please share your idea (or ideas) by clicking on "post a comment" at the TC Blog. We eagerly await your insightful, inspiring ideas. The contest closes for submission on 1 October 2010. The editorial team will compile all the suggestions, choose a set of finalists, and put the final decision to a vote by TC Blog readers.

http://blogs.bmj.com/tc/
Competing interests Ruth Malone owns one share each of Philip Morris/Altria, Philip Morris International and Reynolds American tobacco company stock for research and advocacy purposes. She served as a tobacco industry documents consultant for the US Department of Jutice in USA vs Philip Morris et al.

Provenance and peer review Not commissioned; not externally peer reviewed.

Tobacco Control 2010;19:261-262.

doi:10.1136/tc.2010.038588

\section{REFERENCES}

1. Legresley E. A 'vector analysis' of the tobacco epidemic. Bulletin von Medicus Mundi Schweiz No 72. 1999. http://www.medicusmundi.ch/mms/ services/bulletin/bulletin199901/kap01/03legresley. html.
2. Taylor C. Theories of meaning. In: Philosophical papers I, Human agency and language. Cambridge, UK: Cambridge University Press, 1985:248-62.

3. McDaniel PA, Malone RE. The role of corporate credibility in legitimizing disease promotion. Am J Public Health 2009:99:452-61.

4. Wiist WH. Public health and the anticorporate movement: rationale and recommendations. Am J Public Health 2006;96:1370-5.

5. Freudenberg $\mathbf{N}$. Public health advocacy to change corporate practices: implications for health education practice and research. Health Educ Behav 2005: 32:298-319.

6. Balbach ED, Smith EA, Malone RE. How the health belief model helps the tobacco industry: individuals, choice, and "information". Tob Control 2006; 15(Suppl 4):iv37-43.

7. Chapman S. Public health advocacy and tobacco control: making smoking history. Oxford, UK: Blackwell, 2007.

\section{The lighter side}

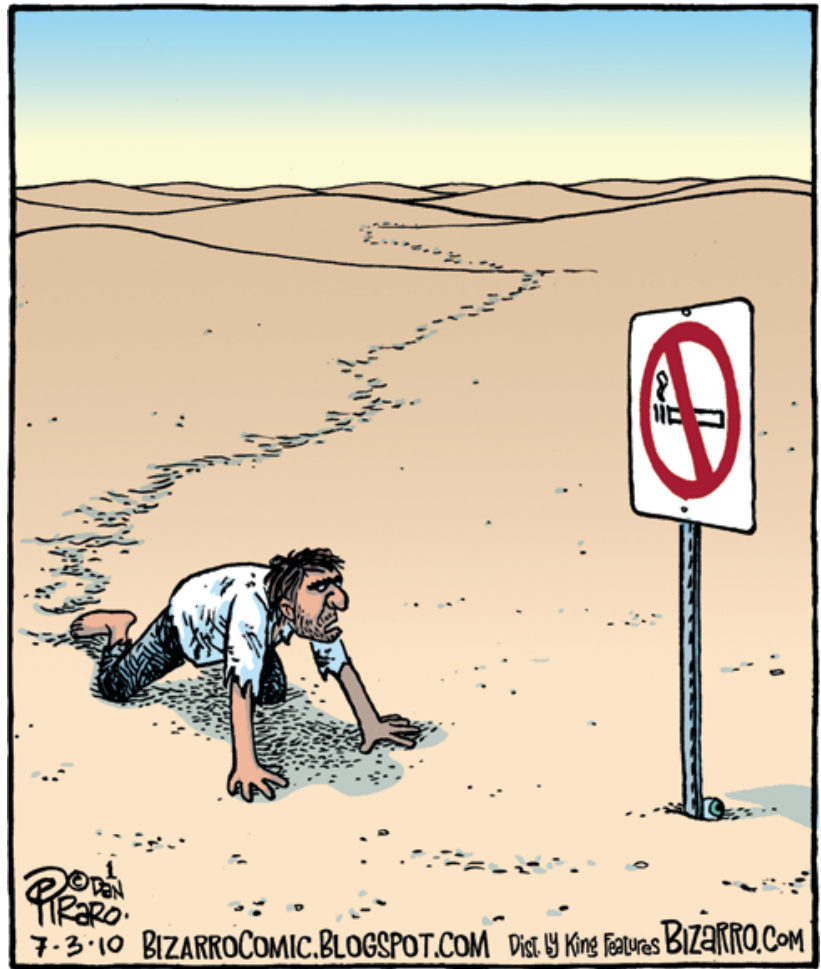

Bizarro, by Piraro. (c) King Features Syndicate.

Reprinted with permission - Torstar Syndication Services. 